\title{
Evaluation of Compressive Strength of Decayed Wood in Magnolia obovata
}

\author{
Kahoru Matsumoto, Futoshi Ishiguri, Kazuya lizuka, Shinso Yokota, Naoto Habu, \\ and Nobuo Yoshizawa
}

\begin{abstract}
To obtain the basic information needed to estimate the degree of decay from compressive strength measured using a Fractometer (CS), relationships between CS and the contents of chemical components were analyzed for Magnolia wood decayed by three types fungi (brown rot, white rot, and soft rot fungi) at various decay levels. Weight loss ratio was significantly, negatively correlated with CS in woods decayed by brown rot and white rot fungi. In addition, a relatively high correlation coefficient was recognized between CS and holocellulose or $\alpha$-cellulose content, except for wood decayed by soft rot fungus. The results obtained showed that Fractometer can detect the decrease of CS at relatively early stage of decay.

Key Words. Compressive Strength; Core Sample; Decay Degree; Fractometer; Wood Decay.
\end{abstract}

In standing trees, many nondestructive and semi-destructive testing methods using various instruments have been applied to identify the degree of decay within the tree trunk (Bethge et al. 1996; Johnstone et al. 2007). The Fractometer, which can measure compressive and bending strength using core samples (5 $\mathrm{mm}$ in diameter) obtained from the trunk, is an instrument used for semi-destructive tests in standing trees (Mattheck and Breloer 1994; Mattheck et al. 1995; Bethge et al. 1996; Matheny et al. 1999). Mattheck and Breloer (1994) used a Fractometer to measure the fracture moment in the bending strength (load was applied to tangential surface of core samples), of core samples collected from many tree species growing in Europe. They classified the fracture moment in the bending strength obtained for each species into three categories, green, yellow, and red, to determine the degree of decay in standing trees. In addition, Schwarze et al. (1995) observed anatomical and physical changes of wood decayed by different fungi and used a Fractometer to measure the bending strength of core samples (load was applied to tangential surface of core samples), one of the physical properties of decayed wood. They concluded that, in order to evaluate the safety of standing trees, more data are needed so that the relationship between anatomical changes and changes in physical properties measured by Fractometer in decayed wood can be determined. However, it is very difficult to collect decayed wood samples from standing trees because the decayed part is frequently present in the central position. Therefore, only a few reports concerning the relationship between the degree of decay and bending strength measured by Fractometer are available. On the other hand, in small wood specimens with any defects such as knots, the relationship between the degree of decay and the reduction of mechanical strength has been researched using wood samples decayed in a laboratory (Mizumoto 1966; Fukuda and Haraguchi 1979; Doi and Nishimoto 1986; Curling et al. 2002). To determine the degree of decay in standing trees more accurately, the relationship between the degree of decay and the compressive strength parallel to grain of wood as measured by Fractometer should be examined for a large number of specimens decayed in a laboratory, and the obtained data should be classified according to the level of decay and mechanical properties.

The object of the present study was to obtain basic information in order to clarify the degree of decay based on compressive strength parallel to grain as measured by Fractometer. Wood core samples were decayed by brown rot, white rot, and soft rot fungi in a laboratory. In the present study, these fungi were defined as follows (Schwarze et al. 2000): brown rot fungi could degrade cellulose and hemicellulose, white rot fungi could degrade cellulose, hemicelluloses, and lignin, and soft rot fungi could degrade cellulose, hemicelluloses, and slightly lignin. After a certain period of decay, the compressive strength parallel to grain of each decayed core sample was measured by Fractometer. In addition, the contents of the chemical components (holocellulose, Klason lignin, and $\alpha$-cellulose) in the decayed woods were determined. The relationships between the compressive strength and the contents of chemical components at various decay levels were analyzed for examining the urban tree diagnosis by using the Fractometer.

\section{MATERIALS AND METHODS}

Increment cores $5 \mathrm{~mm}$ in diameter were collected from sapwood of 14-year-old Magnolia obovata Thunb. $(17 \mathrm{~cm})$ diameter at breast height] using a nonsterilized increment borer (Haglöf, Sweden). Sever damages of increment cores were checked by naked eyes and intact increment cores were selected for the following experiment. Thus, increment cores used in the present study microchecks leading to increase of variation of compressive strength measured by Fractometer. Figure 1 shows the schematic diagrams of the experiments. The increment cores were cut into about $3 \mathrm{~cm}$ lengths for the decay test. 
A total of 195 decay test specimens were obtained, 15 of which were used as controls. Before incubation, the other 180 specimens were dried for one day at $60^{\circ} \mathrm{C}$ $\left(140^{\circ} \mathrm{F}\right)$ and then weighed. All of the specimens were sterilized with propylene oxide for two days in a desiccator in vacuo.

A total of 180 specimens were used to test decay by the brown rot fungus Fomitopsis palustris FFPRI 0507, the white rot fungus Trametas versicolor FFPRI 1030, and the soft rot fungus Chaetomium globosum NBRC 6347. F. palustris FFPRI 0507 and T. versicolor FFPRI 1030 were provided by the Forestry and Forest Products Research Institute (Tsukuba, Ibaraki, Japan). C. globosum NBRC 6347 was obtained from the National Institute of Technology and Evaluation (Kisarazu, Chiba, Japan). Each fungus was precultured on a Potato Dextrose Agar (Difco Laboratories, U.S.) slant medium in a test tube $(1.5 \mathrm{~cm}$ in diameter, and $15 \mathrm{~cm}$ in length). After mycelia had spread on the medium, the specimens, in which the moisture content had been adjusted to $50 \%-70 \%$ by dipping into sterilized distilled water, were put onto the medium in test tubes and then were incubated at $26^{\circ} \mathrm{C}\left(78.8^{\circ} \mathrm{F}\right)$ under dark conditions.

In the decay test, 15 specimens per fungus were collected every 15 days up to 60 days immediately following the start of incubation. After the specimens had been recovered

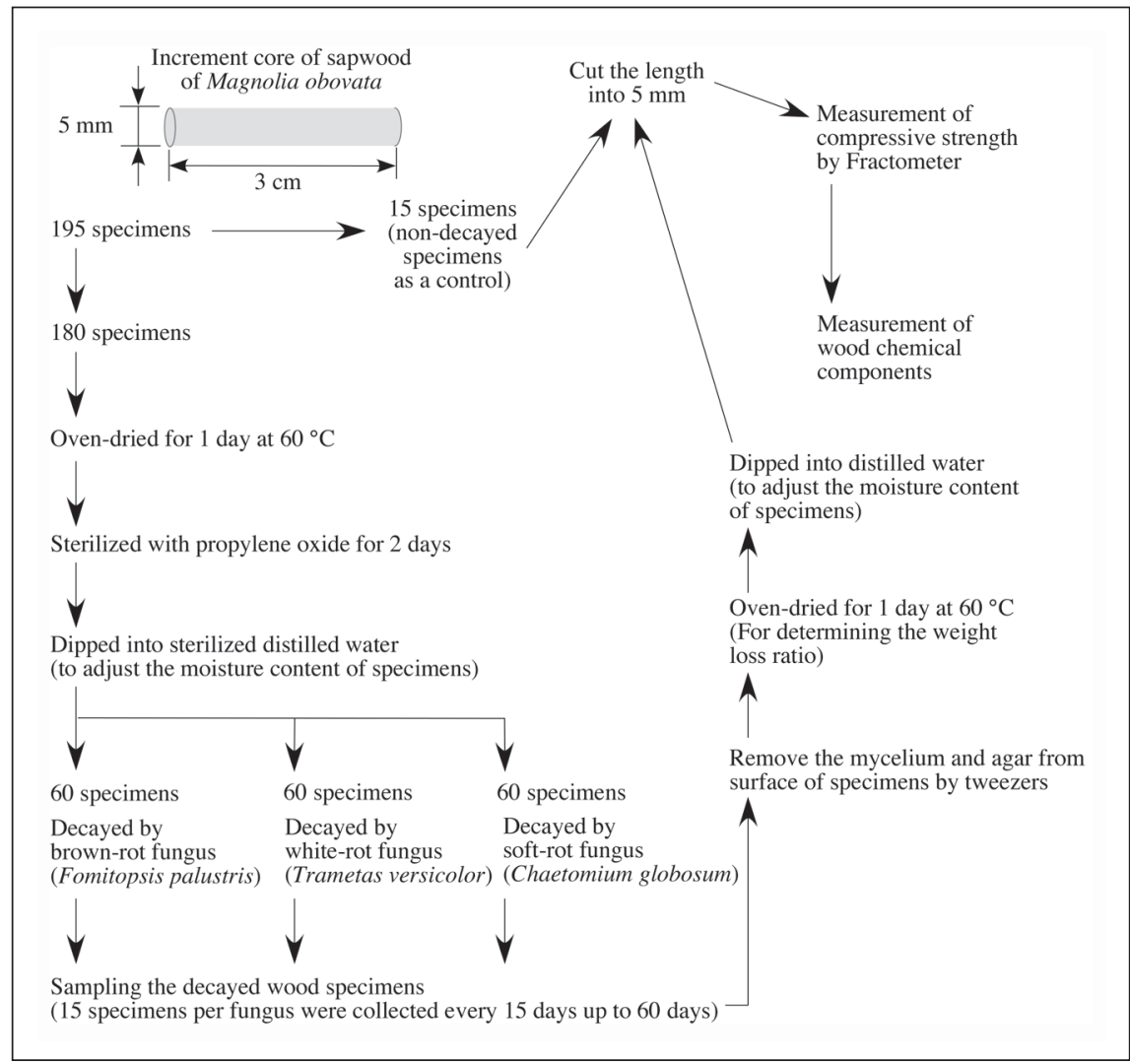

Figure 1. Schematic diagram of the present study.

from the culture, the mycelia were carefully removed from the surface of the decayed specimens. Then the wood samples were oven-dried for one day at $60^{\circ} \mathrm{C}$. The dry weight of the decayed specimens was measured in order to calculate the percentage of weight loss. After the dry weight was measured, the specimens were used for the subsequent experiments.

A total of five sound and 60 decayed specimens were used to measure the compressive strength (CS) by Fractometer (Fractometer II). Five specimens of each fungal species were collected every 15 days up to 60 days after the start of incubation. After the mycelia had been collected from the surface of the decayed specimens, the dry weight of the specimens was measured. The moisture content of the dried specimens was adjusted to $50 \%-70 \%$ with distilled water. To prepare the compressive test specimens ( $5 \mathrm{~mm}$ in diameter, $5 \mathrm{~mm}$ in length), decayed specimens were cut into small pieces about $5 \mathrm{~mm}$ in length. About five compression test specimens were prepared from one decayed specimen. Compressive strength parallel to grain was measured with a Fractometer. To calculate the mean values, about 25 compressive strength values were obtained from about five decayed specimens in each decay period per fungus.

Wood meal was prepared from 15 specimens decayed for each period per fungus. Although residual agar medium on the surface of decayed wood specimen was not affected on the amounts of wood chemical components, mycelium, and agar medium, was carefully removed from surface of decayed wood specimen by tweezers. Wood chemical components (Klason lignin, holocellulose, and $\alpha$-cellulose) were determined ac- cording to the TAPPI test methods (TAPPI 1991). Only one determination was done for chemical components, therefore the statistical analysis for chemical components was excluded.

\section{RESULTS AND DISCUSSION}

\section{Time-Course Changes in Weight Loss, Compres- sive Strength, and Chemical Components of Wood Core Samples}

Figure 2 shows time-course changes in the weight loss ratios of core samples. On the 60th day after the start of decay, the weight loss ratios of wood core samples decayed by brown rot, white rot, and soft rot fungi were $27.4 \%, 45.7 \%$, and $5.4 \%$, respectively. The weight loss ratio by brown rot and white rot fungi increased as the decay period increased. Under the culture conditions in the present study, the weight loss ratio by the white rot fungus always showed higher values than those by the brown rot fungus throughout the decay period, indicating that white rot fungus decayed the specimens more severely than the brown rot fungus did. It is well known that the weight loss ratios of woods decayed by the brown rot fungus show higher values than those decayed by the white rot fungus (Fukuda and Haraguchi 1974). The results obtained in the present study did not correspond to those of the previous reports. However, Yoshimura (1966) reported that the weight loss of wood decayed by T. versicolor (white rot fungus) showed a much higher value than that decayed by $F$. palustris (brown rot fungus) when an agar medium was used for the wood decay 
test. Thus, the difference in the weight loss in wood decayed by F. palustris and T. versicolor might have been affected by the agar medium in the present study. On the other hand, in the soft rot fungus, nearly the same values in weight loss ratio were observed throughout the decay period, indicating the soft rot fungus did not decay the specimens as severely as the other two fungi did during the 60-day period. A soft rot fungus generally shows strong decay ability under very wet conditions. In the present study, the relative humidity in the incubator chamber was not controlled through the test period. Therefore, the weight loss ratio was considered low.

Wood decayed by brown rot fungi becomes brittle and friable, while when decayed by white rot fungi retains much of its strength even at fairly advanced stages of decay (Kollmann and Côté 1984; Schwarze et al. 2000; Schmidt 2006). Time-course changes of CS are shown in Figure 3. Before the decay test, the CS was 24.3 $\mathrm{MPa}$, but it decreased to about $20 \mathrm{MPa}$ within 15 days of decay in all specimens. In brown rot and white rot fungi, nearly constant CS values were found from 15 days to 45 days of decay. However, the CS values decreased markedly on the 60th day: the CS values of specimens decayed by brown rot and white rot fungi were 13.3 and $8.8 \mathrm{MPa}$, respectively. On the other hand, in soft rot fungi, the CS values were nearly constant from 15 to 60 days of decay.

Figure 4 shows time-course changes in the chemical components of wood core samples due to decay by three fungi. The contents of holocellulose, Klason lignin, and $\alpha$-cellulose in nondecayed specimens were $77.6 \%, 21.5 \%$, and $43.4 \%$, respectively. After 60 days of decay, the contents of wood decayed by brown rot fungus were $51 \%, 18.2 \%$, and $23.5 \%$, respectively, indicating that the carbohydrate fraction was markedly decomposed by the brown rot fungus. Fukuda and Haraguchi (1974) reported that the contents of holocellulose markedly decreased in wood decayed by $F$. palustris compared to sound wood. The results obtained for brown rot were similar to those reported by Fukuda and Haraguchi (1974). On the other hand, the contents of wood decayed by the white rot fungus decreased at almost the same rate throughout the decay period. In addition, the fact that weight loss

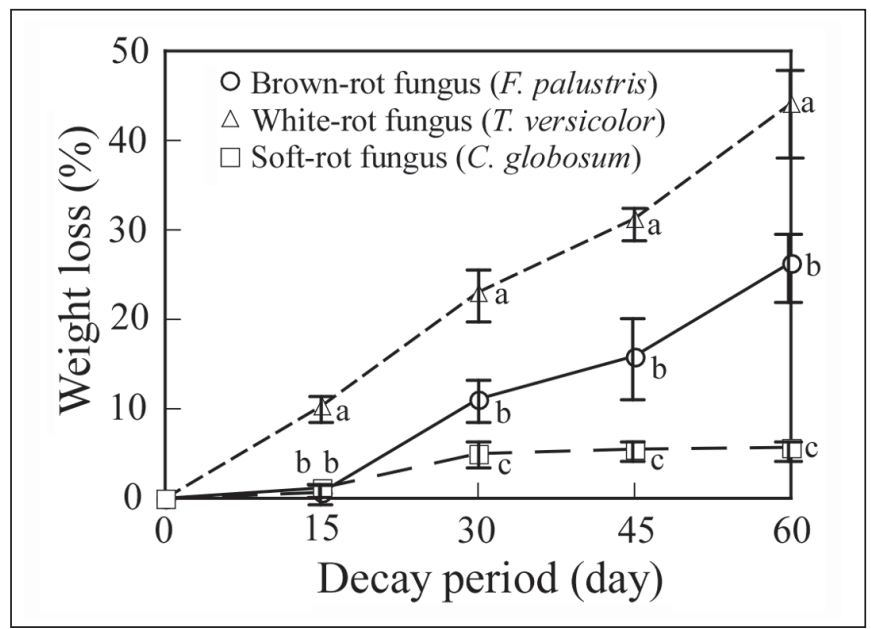

Figure 2. Time-course changes in weight loss of wood core samples of Magnolia obovata. Bars indicate standard deviation. The mean values followed by the different letter indicate significant difference $(P>0.05)$ among the three types of fungi at the same culture period by the Tukey's HSD test. occurred in wood decayed by the white rot fungus suggests that the wood components were significantly decomposed. In general, white rot fungi decompose cellulose, hemicellulose, and lignin at the same rate (Kollmann and Côté 1984; Schwarze et al. 2000; Schmidt 2006); therefore, these contents showed almost constant rates through the decay period. On the other hand, throughout the decay period, nearly the same contents of holocellulose, Klason lignin, and $\alpha$-cellulose were found in wood decayed by the soft rot fungus. This tendency was similar to the results obtained for the weight loss of wood decayed by the soft rot fungus.

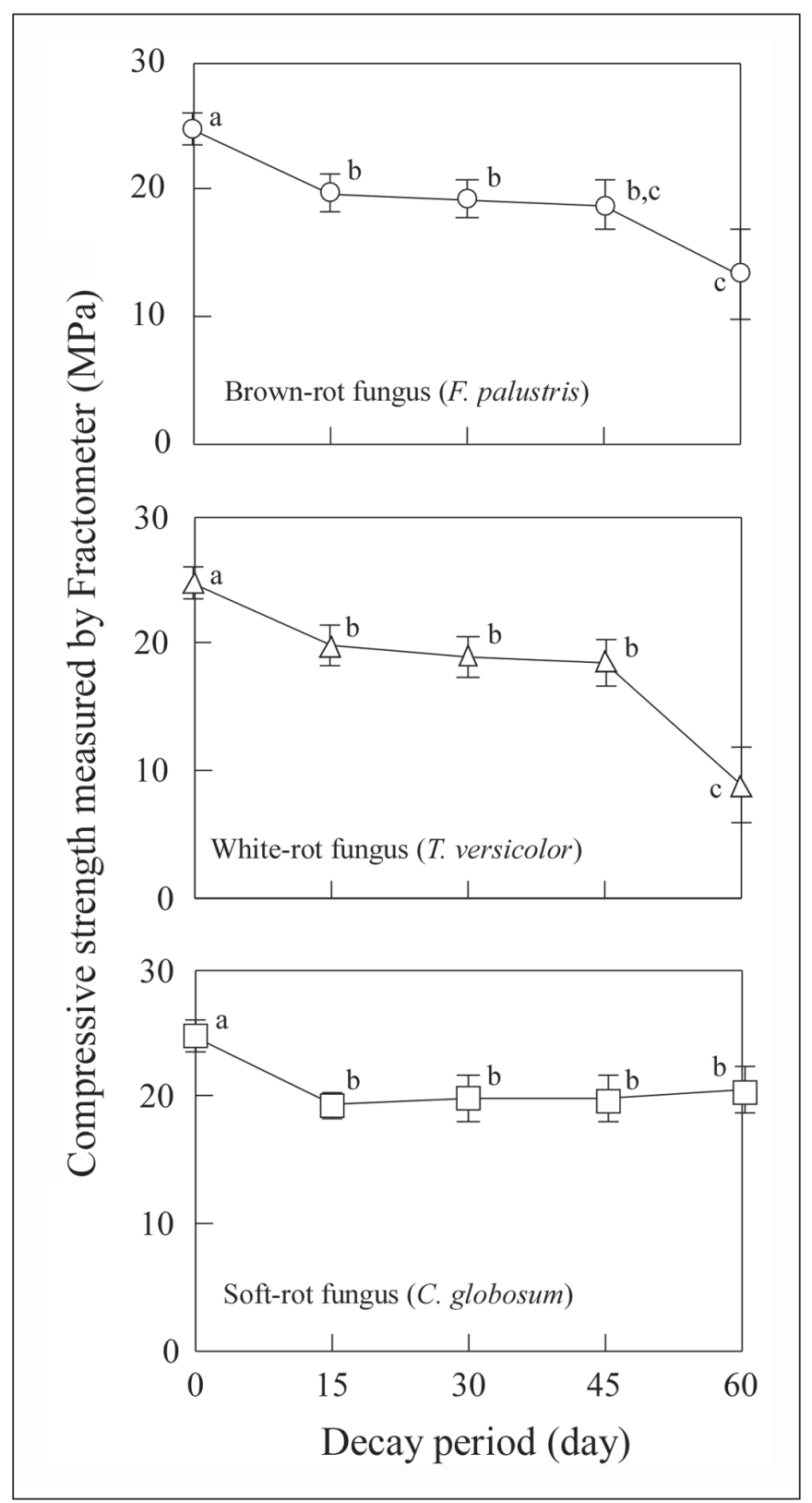

Figure 3. Time-course changes in Fractometer-measured compressive strength in Magnolia obovata. Bars indicate standard deviation. The mean values followed by the different letter indicate significant difference $(P>0.05)$ among the different decay period of a fungus by the Tukey's HSD test. 


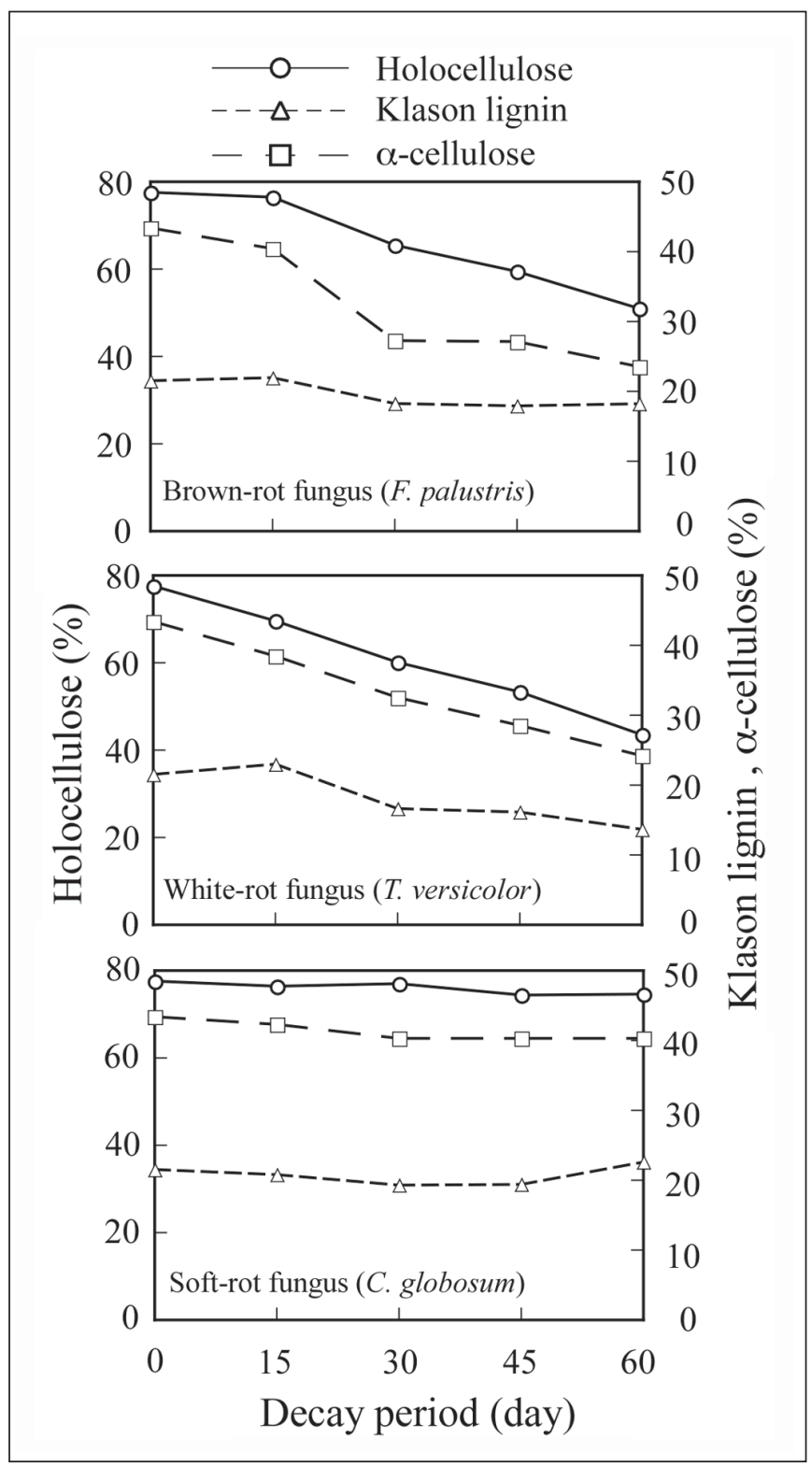

Figure 4. Time-course changes in chemical components of wood core samples of Magnolia obovata.

\section{Relationships Among Compressive Strength, Weight Loss, and Chemical Components of Decayed Wood}

Table 1 shows correlation coefficients among the CS, weight loss, and chemical components of decayed wood. In general, when the wood was decayed by fungi, the wood strength decreased as the weight loss ratio increased. Thus, a negative relationship was recognized between weight loss ratio and strength in decayed wood (Mizumoto 1966; Doi and Nishimoto 1986; Curling et al. 2002). In the present study, high correlation coefficients between weight loss ratio and CS were found in brown rot $(r=-0.909)$ and white rot $(\mathrm{r}=-0.918)$. These results correspond to those of previous studies (Mizumoto 1966; Doi and Nishimoto 1986; Curling et al. 2002). Nearly the same values were observed for weight loss ratio and CS in wood decayed by the soft rot fungus.
In the present study, a significant correlation between CS and holocellulose contents in wood decayed by the brown rot fungus was obtained. In general, the strength of decayed wood decreases because brown rot fungi decompose carbohydrates in the wood cell wall (Kollmann and Côté 1984; Schwarze et al. 2000; Schmidt 2006). Thus, in the present study, the reduction of CS in wood decayed by the brown rot fungus seemed to be caused by the decomposition of cellulose and hemicelluloses in the wood cell wall. There were significant positive correlations among CS, holocellulose, and $\alpha$-cellulose in white rotted wood. As explained before, white rot fungi decompose cellulose, hemicellulose, and lignin at the same rate (Kollmann and Côté 1984; Schwarze et al. 2000; Schmidt 2006). Therefore, in the present study, the CS of white rotted wood was greatly affected by carbohydrate contents. Compared to the brown rot and white rot fungi, in soft rotted wood, large amounts of the main wood chemical components in the cell wall remained. Thus, no significant correlations between CS and chemical components were obtained for soft rotted wood.

Table 1. Correlation coefficients among compressive strength, weight loss, and chemical components of decayed wood in Magnolia obovata.

\begin{tabular}{lllcc}
\hline Factor 1 & Factor 2 & $\begin{array}{l}\text { Brown-rot } \\
(\mathrm{n}=5)\end{array}$ & $\begin{array}{l}\text { White-rot } \\
(\mathrm{n}=5)\end{array}$ & $\begin{array}{l}\text { Soft-rot } \\
(\mathrm{n}=5)\end{array}$ \\
\hline & Weight loss & $-0.909^{\mathrm{z}}$ & $-0.918^{\mathrm{y}}$ & $-0.562 \mathrm{~ns}$ \\
$\mathrm{CS}$ & Klason lignin & $0.696 \mathrm{~ns}$ & $0.768 \mathrm{~ns}$ & $0.488 \mathrm{~ns}$ \\
& Holocellulose & $0.903^{\mathrm{z}}$ & $0.916^{\mathrm{z}}$ & $0.508 \mathrm{~ns}$ \\
& $\alpha$-cellulose & $0.864 \mathrm{~ns}$ & $0.890^{\mathrm{z}}$ & $0.672 \mathrm{~ns}$ \\
\hline
\end{tabular}

${ }^{\mathrm{z}}$ Significance at $5 \%$ level.

y Significance at $1 \%$ level.

$\mathrm{CS}=$ Compressive strength measured by Fractometer; brown-rot decay by F. palustris; white-rot decay by $T$. versicolor; soft-rot decay by $C$. globosum; ns = no significance; $\mathrm{n}=$ number of samples.

\section{CONCLUSION}

Sever decay of tree stems can occur unexpectedly by wind and other environmental factors. For preventing unexpected tree felling, urban tree managers should know the degree of decay of trees. In addition, accuracy of decay diagnosis of trees should be improved. In the present study, we clarified the relationships among CS, weight loss ratio, and chemical components in decayed Magnolia wood by three different types of fungi in laboratory condition. The data obtained would help further more accurate diagnosis of decay in standing trees. In addition, decrease of CS was recognized at relatively low values of weight loss ratio, indicating that Fractometer can detect the decrease of CS at relatively early stage of decay. Increase of weight loss ratio and decrease of CS might be caused by cell wall degradation by fungus. Further research is needed in order to clarify the relationship between the cell wall degradation observed by microscopy and the degree of wood decay. Although, we used only one species, relationships among CS, weight loss ratio, and chemical components might differ among the species. Thus, further research is needed for other species. By combining the results of future studies with those of the present study, a more accurate diagnosis of decay in a standing tree for many species would be obtained. 


\section{LITERATURE CITED}

Bethge, K., C. Mattheck, and E. Hunger. 1996. Equipment for detection and evaluation of incipient decay in trees. Arboricultural Journal 20:13-37.

Curling, S., C.A. Clausen, and J.E. Winandy. 2002. Relationships between mechanical properties, weight loss, and chemical composition of wood during incipient brown-rot decay. Forest Products Journal 52(7):34-39.

Doi, S., and K. Nishimoto. 1986. The bending strength and the chemical components of ezomatsu (Picea jezoensis) wood decayed by the dry rot fungus, Serpula lacrymans. Mokuzai Gakkaishi 32:724-729.

Fukuda, K., and T. Haraguchi. 1974. Difference between brown and white rotted woods. II. Bulletin of the Experiment Forests, Tokyo University of Agriculture and Technology 11:25-29.

Fukuda, K., and T. Haraguchi 1979. Several properties of katsura wood decayed by a soft-rot fungus, Chaetomium globosum Kunze. Bulletin of the Experiment Forests, Tokyo University of Agriculture and Technology 15:107-111.

Johnstone, D.M., P.K. Ades, G.M. Moore, and I.W. Smith. 2007. Predicting wood decay in eucalyptus using an expert system and the IMLResitograph drill. Arboriculture \& Urban Forestry 33:76-82.

Kollmann, F.F.P., and W.A. Côté. 1984. Principles of Wood Science and Technology, Volume I: Solid wood. Springer-Verlag, Berlin Heidelberg New York Tokyo. 592 pp.

Matheny, N.P., J.R. Clark, D. Attewell, K. Hillery, A.W. Graham, and G. Posner. 1999. Assessment of fracture moment and fracture angle in 25 tree species in the United States using the Compressive strength, Fractometer. Journal of Arboriculture 25:18-23.

Mattheck, C., and H. Breloer. 1994. Field guide for visual tree assessment (VTA). Arboricultural Journal 18:1-23.

Mattheck, C.G., H. Breloer, K.A. Bethge, W.A. Albrecht, and A.W. Zipse. 1995. Use of the Fractometer to determine the strength of wood with incipient decay. Journal of Arboriculture 21:105-112.

Mizumoto, S. 1966. The effect of decay caused by Gloeophyllum trabeum on the strength properties of Japanese red pine sap-wood. Journal of the Japanese Forestry Society 48:7-11.

Schmidt, O. 2006. Wood Rot In: Wood and Tree Fungi - Biology, Damage, Protection, and Use, pp. 135-159. Springer-Verlag Berlin Heidelberg.

Schwarze, F.W.M.R., J. Engels, and C. Mattheck. 2000. Fundamental aspects, pp. 5-31. In: Fungal Strategies of Wood Decay in Trees. Springer-Verlag Berlin Heidelberg New York.

Schwarze, F.W.M.R., D. Lonsdale, and C. Mattheck. 1995. Detectablility of wood decay caused by Ustulina deusta in comparison with other tree-decay fungi. European Journal of Forest Pathology 25:327-341.

TAPPI. 1991. TAPPI Test Method, Volume I, Tappi press, the United States of America.

Yoshimura, M. 1966. Studies on wood decay IV: Effect of some factors upon wood decay in laboratory tests (3). The Bulletin of the Faculty of Agriculture, Mie University 34:59-71.

\section{Kahoru Matsumoto}

Graduate Student, Graduate School of Agriculture

Utsunomiya University

Utsunomiya 321-8505, Japan

Futoshi Ishiguri (corresponding author)

Associate Professor, Faculty of Agriculture

Utsunomiya University

Utsunomiya 321-8505, Japan

ishiguri@cc.utsunomiya-u.ac.jp
Kazuya Iizuka

Associate Professor, Faculty of Agriculture

Utsunomiya University

Utsunomiya 321-8505, Japan

Shinso Yokota

Associate Professor, Faculty of Agriculture

Utsunomiya University

Utsunomiya 321-8505, Japan

Naoto Habu

Associate Professor, Faculty of Agriculture

Utsunomiya University

Utsunomiya 321-8505, Japan

Nobuo Yoshizawa

Professor, Faculty of Agriculture

Utsunomiya University

Utsunomiya 321-8505, Japan

Résumé. Afin d'obtenir l'information de base nécessaire pour estimer le degré de carie à partir de mesures de résistance à la compression en utilisant le Fractometer, la relation entre la résistance à la compression et le contenu en composés chimiques a été analysée dans du bois de Magnolia carié par trois types de champignons (carie brune, carie blanche, carie molle) à divers degrés de carie. Le ratio de perte de masse était significatif et négativement corrélé avec la résistance à la compression dans les bois affectés par la carie brune et la carie blanche. D'autre part, un coefficient de corrélation relativement élevé a été observé entre la résistance à la compression et le contenu en holocellulose ou $\alpha$-cellulose, à l'exception du bois carié par la carie molle. Les résultats obtenus montrent que la Fractometer peut détecter la diminution de résistance à un stade relativement tôt de la carie.

Zusammenfassung. Zum Erhalt grundsätzlicher Informationen über die mit einem Fraktometer gemessene Holzdichte zur Bestimmung des Fäulegrades wurden die Beziehungen zwischen der Holzdichte und dem Gehalt an chemischen Komponenten von Magnalia-Holz analysiert, welches durch drei verschiedene Fäuleerreger (Braun-, Weiß-, Moderfäule) bereits unterschiedlich stark abgebaut wurde. Das Gewichtsverlust-Verhältnis war deutlich negativ korreliert mit der Holzdichte in Holz, welches durch Braun- und Weißfäule abgebaut wurde. Darüberhinaus bestand ein relativ hoher Korrelationskoeffizient zwischen Holzdichte und dem Holozellulose- oder $\alpha$-Zelluloseanteil, außer bei Holzabbau durch Moderfäule. Die Ergebnisse zeigten, daß das Fraktometer den Abbau von Holzdichte schon in einem relativ frühen Stadium von Fäule aufzeigen kann.

Resumen. Para obtener la información básica necesaria con el fin de estimar el grado de descomposición de la madera se usó un Fractómetro (CS), relacionando CS y los contenidos de componentes químicos. Fueron analizados para madera descompuesta de Magnolia para tres tipos de hongos (café, blanco y blando) en varios niveles de decaimiento. La pérdida de peso fue significativa, correlacionado negativamente con CS en maderas descompuestas para hongos café y blanco. Además, se encontró un coeficiente de correlación alto entre CS y holocelulosa o contenido de $\alpha$ celulosa, excepto para madera decaída por el hongo suave. Los resultados mostraron que el Fractómetro puede detectar la disminución de CS en etapas relativamente tempranas del decaimiento. 